\title{
PEMANFAATAN LIMBAH KULIT IKAN TUNA MENJADI KERUPUK
}

\author{
Utilization of Tuna Fish Skin Waste into Chips \\ Satria Wati Pade ${ }^{1}$, Arif Murtaqi Akhmad Mutsyahidan ${ }^{2 *}$, Fredy Irawan $^{3}$ \\ ${ }^{1,2,3)}$ Dosen Program Studi Teknologi Hasil Pertanian, Politeknik Gorontalo \\ *E-mail : arifmams@poligon.ac.id
}

\begin{abstract}
ABSTRAK
Ikan tuna banyak disukai masyarakat dan memiliki nilai yang ekonomis. Ikan tuna (Thunus albacares) berpotensi cukup tinggi dengan kandungan protein tinggi $\pm 26 \mathrm{~g} / 100 \mathrm{~g}$ daging dan kadar lemak rendah yaitu $\pm 2,7 \mathrm{~g} / 100$ daging. Kandungan gizi lain : mineral yaitu fosfor, kalsium, zat besi, sodium, Vit. A dan Vit. B. Ikan tuna memiliki nilai ekonomis cukup tinggi karena dapat diolah menjadi berbagai macam produk : Fillet, bakso, siomay, nugget, sosis, empek-empek dan kerupuk. Pelatihan dalam pemanfaatan kulit ikan tuna ini memiliki tujuan untuk meningkatkan perekonomian ibu-ibu di daerah pantai di kelurahan Tanjung Kramat, Kota Gorontalo..
\end{abstract}

\section{Kata kunci: Kulit ikan, Tuna, Kerupuk}

\begin{abstract}
Tuna is very popular with consumers and has a high value. Tuna (Thunus albacares) contains $\pm 26 \%$ protein and $\pm 2.7 \%$ fat. Other nutritional content: minerals, namely phosphorus, calcium, iron, sodium, Vit. A and Vit. B. Tuna fish has a high economic value because it can be processed into various kinds of products: fillets, meatballs, dumplings, nuggets, sausages, empek-empek and crackers. The training in utilizing tuna skin has the aim of improving the economy of women in coastal areas in the Tanjung Kramat sub-district, Gorontalo City.
\end{abstract}

\section{Key words: Fish skin, Tuna, Chips.}

\section{PENDAHULUAN}

Gorontalo memiliki potensi yang tinggi di bidang perikanan. Sebagian besar masyarakat pesisir pantai di Gorontalo sangat bergantung pada hasil ikan. Kelurahan Tanjung Kramat merupakan daerah yang terdapat di daerah pesisir pantai dan banyak masyarakat di daerah ini menggantungkan perekonomiannya dengan menjadi nelayan.

Meskipun termasuk wilayah kota, Kelurahan Tanjung Kramat dapat dikategorikan daerah yang jauh dari pusat kota. Kondisi jalan menuju daerah ini juga cukup berkelok-kelok dan naik turun. Kondisi ini menyebabkan sebagian masyarakatnya masih tertinggal dibanding penduduk di pusat kota.

Pelatihan dalam pemanfaatan ikan tuna di kelurahan tanjung kramat dilaksanakan dalam rangka membantu perekonomian warga terutama ibu-ibu yang sebagian besar merupakan ibu rumah tangga. Pemanfaatan limbah kulit ikan tuna dilakukan mengingat masih banyaknya limbah ikan tuna khususnya kulit ikan tuna yang ternyata bisa memiliki nilai jual ketika diolah. 


\section{METODE PELAKSANAAN KEGIATAN}

Pelatihan pembuatan kerupuk ikan tuna dilaksanakan pada bulan Februari tahun 2021 di Kelurahan Tanjung Kramat Kota Gorontalo pada pukul 8.00 WITA. Pelaksanaan kegiatan pengabdian dilakukan dalam beberapa tahap antara lain; identifikasi masalah, pencarian solusi, dan kegiatan pengarahan di lapangan.

1) Identifikasi masalah diawali dengan peninjauan sebelum kegiatan untuk mencari permasalahan yang akan dicarikan solusi.

2) Pencarian solusi dilakukan dengan cara mengumpulkan saran dari masyarakat dan dikaji untuk mencari solusi yang relevan dengan kondisi di lapangan

3) Kegiatan pengarahan di lapangan dilakukan dengan melakukan pelatihan, diskusi dan praktek.

\section{HASIL DAN PEMBAHASAN}

Hasil dari kegiatan ini dapat dilihat dari respon dan manfaat yang dirasa oleh masyarakat. Masyarakat sangat antusias ketika mengikuti pelatihan pemanfaatan kulit ikan tuna. Hal ini disebabkan karena masyarakat selama ini tidak pernah terpikir bahwa kulit ikan tuna yang biasanya Cuma jadi sampah ternyata dapat diolah menjadi makanan yang enak dan bergizi tinggi. Ikan tuna mengandung sekitar $24 \%$ protein dan seekitar 0,2 - 2,7\% lemak. Selain itu, ikan tuna juga kaya akan mineral dan vitamin (Stansby dan Olcott, 1963). Kulit ikan tuna ternyata mengandung protein lebih tinggi dibanding daging ikan tuna. Kulit ikan tuna mengandung protei sekitar 37,32\% (Hadinoto dan Idrus, 2018).

Keterampilan yang didapat oleh ibu-ibu dapat terlihat saat ibu-ibu ikut praktek membuat kerupuk ikan tuna. Selain pelatihan pembuatan kerupuk ikan tuna, ibuibu juga dilatih bagaimana mengemas dan memilih kemasan yang tepat karena sifat dari kerupuk ikan tuna yang mudah menyerap air (higroskopis). Bahan pangan yang higroskopis akan mudah mlempem jika kontak dengan udara bebas.

Kegiatan pengabdian berjalan dengan baik. Masyarakat dan aparat desa sangat mengapresiasi kegiatan ini. Kegiatan ini dilaksanakan dengan tetap mematuhi protokol kesehatan selama pandemi covid19. Berikut gambar kegiatan pengabdian oleh tim :

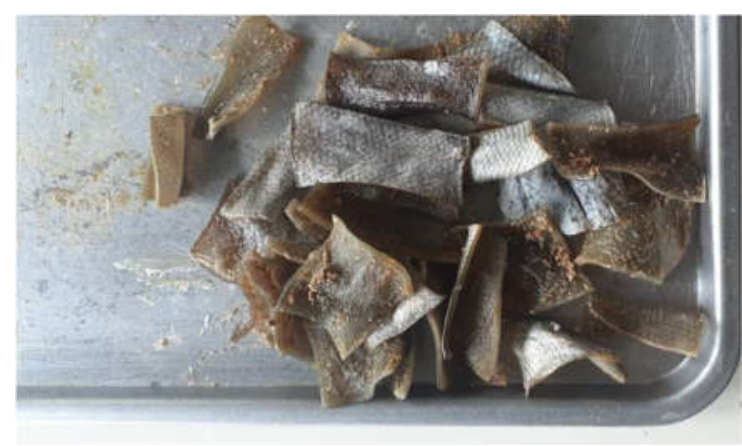

Gambar 1. Produk mentah kulit ikan tuna

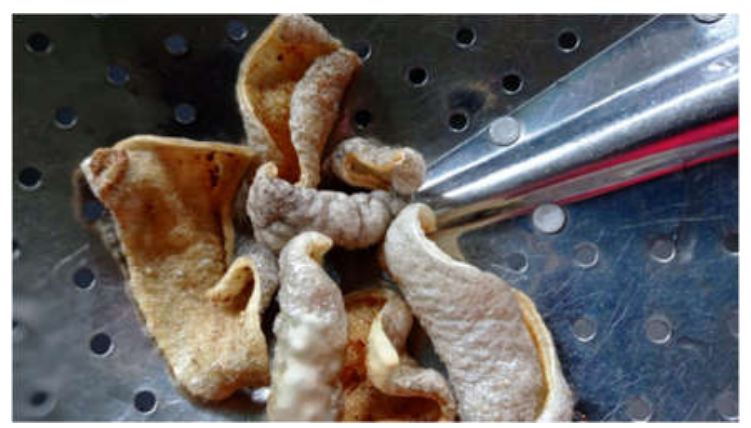

Gambar 2. Produk utama olahan

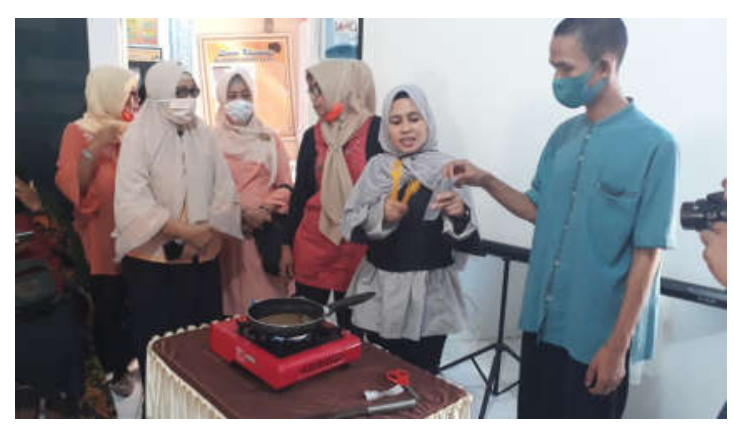

Gambar 3. Proses pelatihan kepada masyarakat

\section{KESIMPULAN}

Kegiatan ini berjalan dengan baik atas kerja sama semua pihak. Masyarakat 
memperoleh manfaat keterampilan dalam memanfaatkan limbah ikan tuna yang dapat bernilai jual ketika diolah.

\section{DAFTAR PUSTAKA}

Hadinoto S, Idrus S. 2018. Proporsi dan kadar proksimat bagian tubuh ikan tuna Ekor kuning (Thunnus ibacares) dari perairan maluku. Majalah Biam 14 (02) Desember 51-57

Stansby ME, Olcott HS. 1963. Composition of Fish. Di dalam: Stansby ME, Dassow JA, editor. Industrial Fishery Technology. London: Reinhold Publishing Co. 